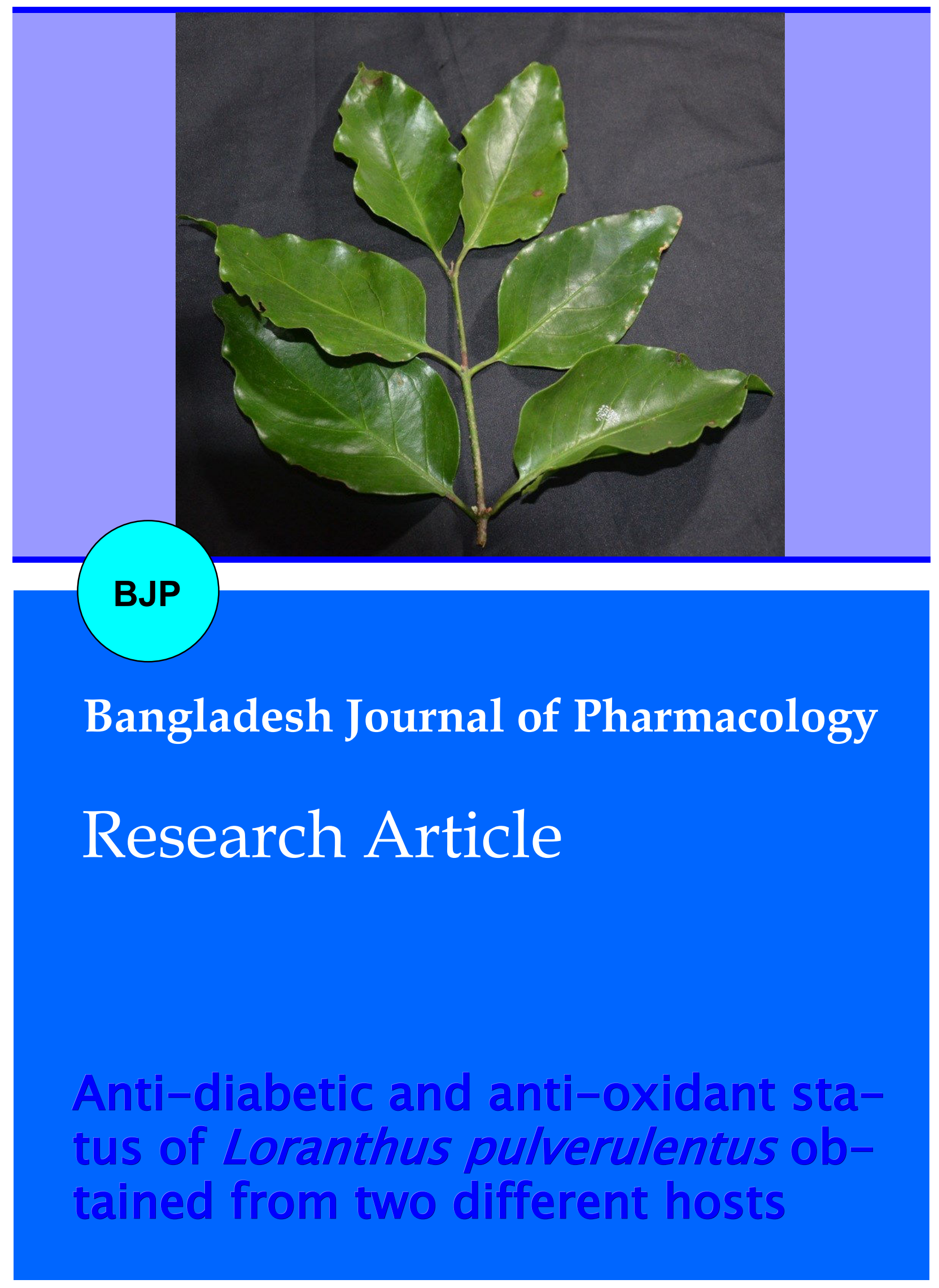




\title{
Anti-diabetic and anti-oxidant status of Loranthus pulverulentus obtained from two different hosts
}

\author{
Sairah Hafeez Kamran', Mobasher Ahmad', Durre Shahwar² and Muhammad Ajaib3 \\ ${ }^{1}$ University College of Pharmacy, University of the Punjab, Allama lqbal Campus, Lahore 54 000, Pakistan; \\ Department of ${ }^{2}$ Chemistry and ${ }^{3}$ Botany, Government College University, Lahore 54 000, Pakistan.
}

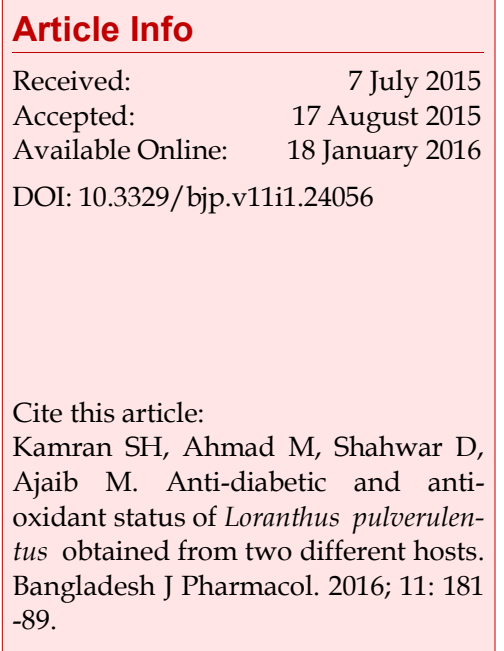

\begin{abstract}
Leaves of Loranthus pulverulentus have been used ethnically in Pakistan for controlling blood glucose levels. The present study was designed to investigate the anti-diabetic and anti-oxidant potential of the methanolic extracted fractions of L. pulverulentus obtained from two different hosts' viz. Dalbergia sissoo and Populus nigra. The acute study demonstrated that L. pulverulentus (D. sissoo) leaves possess significant blood glucose lowering effect whereas $L$. pulverulentus ( $P$. nigra) was didn't significantly decreased blood glucose levels. The n-butanol fraction of L. pulverulentus (D. sissoo) also significantly increased in vivo total anti-oxidant activity on eighth day after treatment and blood glucose levels were significantly reduced (\%46.7) when compared to the control diabetic group (\% $\uparrow 198.1)$ and metformin treated group (\% $\downarrow 25.9)$. Leaves of L. pulverulentus (D. sissoo) have good margin of safety as therapeutic index is 3.5. This study provides scientific evidence that leaves of $L$. pulverulentus (D. sissoo) possess potential anti-diabetic activity whereas $L$. pulverulentus (P. nigra) was not found effective in diabetic illness.
\end{abstract}

\section{Introduction}

Loranthus pulverulentus Wall. locally called 'Parwikh' belongs to Loranthaceae family and grows at higher altitudes. It grows on different hosts like Dalbergia sissoo, Olea ferruginea, Populus nigra, Mallotus phillipensis and Acacia modesta. The leaves of the plant have been identified in folk use in District Kotli, Azad Kashmir for the treatment of diabetes and wounds (Ajaib et al., 2010).

The present study was designed to assess and evaluate the anti-diabetic activity in correlation with anti-oxidant properties of L. pulverulentus obtained from Dalbergia sissoo and Populus nigra. The literature survey indicates no pharmacological validation on this plant.

\section{Materials and Methods}

Methanol, $n$-hexane, ethyl acetate, chloroform and nbutanol were obtained from Merck (Germany). UV spectra and UV visible spectra was recorded using Shimadzu, Japan. 1,1-diphenyl-2-picrylhydrazyl (DPPH), gallic acid, quercetin, butylated hyroxytoluene (BHT), Folin \& Ciocalteu's phenol reagent, sodium nitrite, thiobarbituric acid, uric acid, sodium carbonate, aluminium chloride, acetic acid, sodium benzoate and ceric sulfate were purchased from Sigma-Aldrich. All other chemicals used were of analytical grade.

\section{Plant materials}

L. pulverulentus that grows on Dalbergia sissoo and Populus nigra was collected from Kotli, Azad Kashmir in April 2013 and January 2014. The plant sample was identified by a Taxonomist, Dr. Muhammad Ajaib, Botany department, Government College University, Lahore and voucher number GC/Herb/Bot/1613 and GC/Herb/Bot/2726 were issued. 


\section{Extraction procedure}

Fresh leaves of both varieties of L. pulverulentus were separated from stems. Stem $(7 \mathrm{~kg})$ and leaves $(5 \mathrm{~kg})$ were chopped and steady state extraction with methanol (>72 hours) was done to avoid destruction of thermolabile components. The methanol was evaporated at $40^{\circ} \mathrm{C}$ using rotary evaporator (Heidolph). The extract was completely dried and stored in refrigerator at $4-8^{\circ} \mathrm{C}$. The methanolic extract was weighed, triturated with water and filtered. The filtrate was fractionated with $n$-hexane, ethyl acetate, chloroform and $n$-butanol $(30 \mathrm{~mL} \times 3)$. All the extracts were dried and stored at $4-8^{\circ} \mathrm{C}$ until use.

\section{Phytochemical screening}

Phytochemical tests using standard reagents and procedures were carried out on methanolic extracts of leaves and stems of both varieties separately. Standard reagents and procedures were used to test the presence of alkaloids, saponins, triterpenoids, carbohydrates, proteins, tannins and glycosides (Evans, 2009).

\section{Anti-oxidant assays}

\section{DPPH radical scavenging activity}

The assay was performed according to method reported elsewhere (Ishtiaq et al., 2014). Different concentrations $(1000,500,250,120,60 \mu \mathrm{g} / \mathrm{mL})$ of various fractions were added to $0.1 \mathrm{mM}$ methanolic solution of DPPH (3 $\mathrm{mL}$ ). The mixture was shaken and allowed to stand in dark for one hour. The absorbance was measured at 517 $\mathrm{nm}$ against methanol as blank. Lower absorbance indicates high radical scavenging activity. All the samples were assayed in triplicate.

$\%$ Radical scavenging activity $=\left(\mathrm{A}_{\text {Control- }} \mathrm{A}_{\text {Sample }}\right) /$ $\mathrm{A}_{\text {Control }} \times 100$

\section{Total anti-oxidant activity}

Various fractions ( $n$-hexane, ethylacetate, chloroform, $n$ butanol and aqueous) of both varieties were evaluated for anti-oxidant status by phosphomolybdenum complex formation (Gokturk et al., 2007). Phosphomolybdenum reagent $\left(0.6 \mathrm{M} \mathrm{H}_{2} \mathrm{SO}_{4} 4 \mathrm{mM}\right.$ ammonium molybdate and $28 \mathrm{mM}$ sodium phosphate) was added to 500 $\mu \mathrm{g} / \mathrm{mL}$ of each fraction sample in capped vial. These vials were incubated on water bath at $95^{\circ} \mathrm{C}$ for $90 \mathrm{~min}$ and the absorbance of the samples was measured at 695 $\mathrm{nm}$ after cooling the samples. All samples were assayed in triplicate and the anti-oxidant activity was expressed relative to $\mathrm{BHT} \mathrm{mg} / \mathrm{g}$.

\section{Determination of total phenolic content}

Total phenolic content of various fractions of leaves and stems were determined spectrophotometrically using the method (Singleton et al., 1999). To $200 \mu \mathrm{g} / \mathrm{mL}$ of each fraction, $10 \%$ Folin-Ciocalteu $(1.5 \mathrm{~mL})$ was added and the test tubes were kept in dark for $5 \mathrm{~min} .5 \%$
$\mathrm{Na}_{2} \mathrm{Co}_{3}$ was added to the solution and absorbance was measured after 40 minutes at $725 \mathrm{~nm}$ on UV-visible spectrophotometer. Total phenols were expressed as milligrams of Gallic acid equivalents (GAE) using standard calibration curve. Results were expressed as GAE $\mathrm{mg} / \mathrm{g}$.

\section{Total flavonoid determination by colorimetric method}

Total flavonoids were estimated by method (Singleton et al., 1999). $250 \mu \mathrm{g} / \mathrm{mL}$ of every fraction was taken and $75 \mu \mathrm{L}$ of $5 \%$ sodium nitrite was added followed by the addition of $150 \mu \mathrm{L}$ of $10 \%$ aluminium chloride. The reaction was completed by the addition of $500 \mu \mathrm{L}$ of $5 \%$ sodium hydroxide. Then $1.25 \mathrm{ml}$ of deionized water was added to all test tubes. The absorbance was measured at $510 \mathrm{~nm}$. Calibration curve was constructed using quercetin as standard and results were expressed in terms of quercetin equivalent ( $\mathrm{mg}$ of Quer/g of extract).

\section{Anti-diabetic evaluation}

\section{Animals}

Balb C male mice $(25-30 \mathrm{~g})$ were obtained from the University College of Pharmacy, University of the Punjab. Animals were housed in the animal house of University College of Pharmacy. Animals were kept at $25 \pm 2{ }^{\circ} \mathrm{C}$ with $67 \pm 10 \%$ humidity and provided with standard mice pellet diet and free access to water. Animals were fasted for 12 hours before the experiment.

\section{Induction of diabetes}

Diabetes was induced by intraperitoneal injection of alloxan monohydrate $(150 \mathrm{mg} / \mathrm{kg})$ solution. The solution was prepared in $0.9 \%$ saline and $\mathrm{pH}$ was maintained at 7. On the eight day, blood was withdrawn from tail vein of mice deprived of food for 12 hours with free access to water, for estimation of glucose by glucose oxidase spectrophotometric method. Animals with glucose levels between $200-350 \mathrm{mg} / \mathrm{dL}$ were selected for study.

Hypoglycemic effect of single dose of methanolic extracts of L. pulverulentus (D. sissoo) and L. Pulverulentus (P. nigra)

After induction of diabetes and determining fasting blood glucose levels (200-350 mg/dL) Balb/c male mice $(n=5)$ were divided into five groups. After administration of single dose of extracts $(250 \mathrm{mg} / \mathrm{kg})$, blood glucose levels were determined at 2, 4, 6, 8, 12 and 24 hours intervals. Blood glucose was determined with glucometer, SD Biosensor (Codefree).

Effect of various fractions of L. pulverulentus (D. sissoo) in alloxan-induced diabetic mice

$\mathrm{Blab} / \mathrm{c}$ male mice were divided into 13 groups $(\mathrm{n}=5)$. The animals were treated with relative extracts and 
metformin for seven days. Metformin was used as positive control. Group I received distilled water $(0.1$ $\mathrm{mL})$; Group II was untreated diabetic mice and received distilled water $(0.1 \mathrm{~mL})$; and Group III diabetic mice received metformin ( $250 \mathrm{mg} / \mathrm{kg}$ body weight) orally in solution form. Groups IV to VIII were given fractions $(n$ -hexane, ethyl acetate, chloroform, $n$-butanol and water) of leaves of L. pulverulentus (D. sissoo) at dosage of 250 $\mathrm{mg} / \mathrm{kg}$ body weight orally. Groups IX to XIII were given orally different fractions of stems of $L$. pulverulentus (D. sissoo) at dose of $250 \mathrm{mg} / \mathrm{kg}$. The vehicle used in all fractions used was distilled water. The $n$-hexane and ethyl acetate fractions were sonicated for $3 \mathrm{~min}$ to completely dissolve the extract. On eighth day mice were sacrificed by cardiac puncture. $500 \mu \mathrm{L}$ blood was deprotenising $10 \%$ trichloroacetic acid and centrifuged. The supernatant were collected and analyzed for glucose levels by glucose oxidase (GOD-PAP) spectrophotometric method. $500 \mu \mathrm{L}$ blood was collected in eppendorf, clotted and centrifuged at 5,000 rpm for 15 min and serum was analysed for in vivo anti-oxidant activity.

\section{Anti-oxidant activity of various fractions of L. Pulve- rulentus (D. sissoo) in vivo}

This assay was performed according to the method described previously (Koracevic et al., 2001). This assay measures the capacity of the serum to inhibit the production of thiobarbituric acid reactive substances (TBARS) from sodium benzoate in the presence of the free radicals derived from the Fenton's reaction. Each sample had its sample blank in which $20 \%$ acetic acid was added before the addition of Fe-EDTA mixture and hydrogen peroxide. Uric acid ( $1 \mathrm{mmol} / \mathrm{L})$ was used as standard. All samples were prepared in triplicate. $10 \mu \mathrm{L}$ of serum was used for analysis from each sample.

Determination of $E D_{50}$ and $L D_{50}$ of L. pulverulentus (D. sissoo)

Male mice were divided into seven groups $(n=5)$. Diabetes was induced and methanolic extracts of leaves and stems dissolved in water, in doses of 100, 250500 , $750,1000,1250,1500 \mathrm{mg} / \mathrm{kg}$ were administered to seven different groups. Blood glucose levels were measured after 6 hours by glucose oxidase (GOD-PAP) method and $\mathrm{ED}_{50}$ of leaves and stems of L. pulverulentus (D. sissoo) was calculated by plotting graphs (Subhan et al., 2010). The methanolic extracts of stems and leaves of L. pulverulentus (D. sissoo) and was studied for their acute toxicity in BALB/c female mice. The test was performed according to OECD guidelines 420 (OECD, 2001). Fixed doses of 100, 250, 500, 2000, 3000, 5000 and $8000 \mathrm{mg} / \mathrm{kg}$ were administered orally to five different groups of female mice $(n=3)$ and observed for next 24 hours for toxicity signs and deaths. Median lethal dose was calculated with the help of graph. The intraperitoneal acute toxicity of methanolic extract of leaves and stems of L. pulverulentus (D. sissoo) was determined in BALB/c mice (20-25g) by using the method of Lorke, (1983). Initially the doses selected were 250, 500, 1000, 2000 and $3000 \mathrm{mg} / \mathrm{kg}$. Five groups of animals $(n=3)$ were intraperitoneally injected methanolic extracts dissolved in double distilled water under aseptic conditions. The animals were observed for 24 hours for any signs of toxicity and death. $\mathrm{LD}_{50}$ was then calculated as the geometric mean of the least dose that killed mice and the highest dose killing none mice.

\section{Statistical analysis}

The data were expressed as the mean \pm SEM for all groups. Statistical analysis of anti-diabetic data, $\mathrm{ED}_{50}$ and $\mathrm{LD}_{50}$ was calculated by plotting graphs using Graph pad prism 5. One way analysis of variance (ANOVA) followed by Dunnett's comparison was applied to calculate the significant difference between groups. Microsoft excel was used for in- vitro study analysis.

\section{Results \\ Extraction}

The yields of methanolic extract of stems and leaves are presented in Table I.

\section{Phytochemical analysis}

The methanolic extract of leaves and stems was screened for different types of constituents. The phytochemical results of both varieties are presented in Table II.

\section{Anti-oxidant assays}

The radical scavenging activity of phenolic compounds on $\mathrm{DPPH}$ is thought to be because of the hydrogen donating ability (ÖnayUçar et al., 2006). Phenolic compounds decrease the absorbance of $\mathrm{DPPH}$ radical because phenols trap the radicals by donating hydrogen. Various concentrations of different fractions of leaves and stems of L. pulverulentus (D. sissoo) and $L$. pulverulentus ( $P$. nigra) were analyzed for their radical scavenging activity and the results are presented in Figure 1.

$\mathrm{DPPH}$ is a reagent used to estimate the free radical scavenging activity of the anti-oxidants. The scavenging ability of various fractions of leaves of L. pulverulentus (D. sissoo) is in following order, $n$-butanol $(92.4 \%) \geq$ ethyl acetate $(92.3 \%)$ >aqueous $(91.15 \%)>$ n-hexane $(86.2 \%)>$ BHT $(62.9 \%)>$ chloroform $(60.7 \%)$. The radical scavenging activity of different fractions increase with the increasing the concentration of the extract could be observed from Figure 1. In stems of L. pulverulentus (D. sissoo) the maximum DPPH radical scavenging ability was found in ethyl acetate fraction $(90.5 \%)$ followed by n-butanol $(88.5 \%), n$-hexane $(85.3 \%)$, aqueous $(84.1 \%)$ and chloroform $(82.8 \%)$ extracts. 
Table I

Percentage yields of methanolic extracts and various fractions of L. pulverulentus from two different hosts

\begin{tabular}{|lcccc|} 
& \multicolumn{2}{c|}{ L. pulverulentus $(D$. sissoo) } & \multicolumn{2}{c|}{ L. pulverulentus (P. nigra) } \\
\cline { 2 - 5 } & Leaves (\%) & Stems (\%) & Leaves (\%) & Stems (\%) \\
Methanolic extract & 10.04 & 3 & 7.21 & 5.21 \\
$n$-Hexane fraction & 1.64 & 5.94 & 4.3 & 2.4 \\
Ethyl acetate fraction & 2.26 & 2.07 & 5.4 & 3.6 \\
Chloroform fraction & 0.41 & 6.21 & 1.2 & 0.98 \\
$n$-Butanol fraction & 4.35 & 2.33 & 3.8 & 2.7 \\
Aqueous fraction & 44 & 54.72 & 22.6 & 19.5 \\
\hline
\end{tabular}

Table II

Phytochemical screening of methanolic extract of L. pulverulentus from two different hosts

\begin{tabular}{|c|c|c|c|c|}
\hline & \multicolumn{2}{|c|}{ L. pulverulentus (D. sissoo) } & \multicolumn{2}{|c|}{ L. pulverulentus (P. nigra) } \\
\hline & Leaves & Stems & Leaves & Stems \\
\hline Saponins & - & - & ++ & ++ \\
\hline Triterpenoids & +++ & ++ & ++ & ++ \\
\hline Alkaloids & ++ & ++ & ++ & ++ \\
\hline Carbohydrates & +++ & +++ & +++ & +++ \\
\hline Flavanoids & +++ & +++ & ++ & ++ \\
\hline Proteins & ++ & ++ & +++ & +++ \\
\hline Tannins & + & + & +++ & +++ \\
\hline Glycosides & +++ & +++ & +++ & +++ \\
\hline
\end{tabular}

Absent, +: merely present, ++: present, +++: intensely present

The total phenolic content of the stems and leaves was calculated according to FC method and was expressed as mg gallic acid equivalent/g of the extract. The highest phenolic content was found in ethyl acetate fraction of the both leaves $(214.5 \pm 3.6)$ and stems $(171.9$ \pm 3 ) of L. pulverulentus (D. sissoo). The $n$-butanol fraction of leaves of L. pulverulentus (D. sissoo) (208.2 \pm 3.1$)$ and L. pulverulentus $(P$. nigra) $(82.4 \pm 0.3)$ contained highest phenolic content (Table III).

Highest flavonoid content was found in aqueous fraction $(837.4 \pm 3.5)$ of leaves of L. pulverulentus (D. sissoo) and in L. pulverulentus ( $P$. nigra) highest flavonoid content was in $n$-butanol fraction $(122.8 \pm 1.1)$ of the leaves (Table III).

The total anti-oxidant activity was estimated by phosphomolybdenum method. The highest antioxidant activity in L. pulverulentus (D. sissoo) leaves was found in $n$-butanol fraction, $666.7 \pm 27.3 \mathrm{mg} / \mathrm{g}$ equivalent to BHT. In L. pulverulentus (P. nigra) the highest anti -oxidant activity was present in aqueous fraction of leaves i.e. $219.8 \pm 0.7 \mathrm{mg} / \mathrm{g}$ equivalent to BHT.

\section{Single dose results at different time intervals}

The single dose study on the methanolic extracts of both varieties of L. pulverulentus has shown that maximum blood glucose reduction capability was present in the methanolic extract of leaves of L. pulverulentus (D. sissoo). Maximum effect with the leaves extract was shown at $6^{\text {th }}$ hour after the dose administration and significant effect was maintained up to 24 hours whereas the methanolic extract of stems didn't maintain the reduction for up to 24 hours. L. pulverulentus ( $P$. nigra) extracts didn't significantly decrease the glucose levels (Table IV).

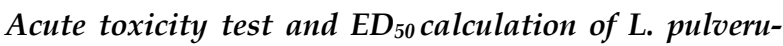
lentus (D. sissoo)

$\mathrm{ED}_{50}$ of methanolic extract of leaves of L. pulverulentus (D. sissoo) calculated from different doses $(100,250,500$, 750, 1250, $1500 \mathrm{mg} / \mathrm{kg}$ ) was $1250 \mathrm{mg} / \mathrm{kg}$ and ED $\mathrm{ED}_{50}$ of stems was $1450 \mathrm{mg} / \mathrm{kg}$. A dose dependent hypoglycemic effect was observed in animals treated with different doses.

$\mathrm{LD}_{50}$ of the leaves administered orally was $6500 \mathrm{mg} / \mathrm{kg}$ and the therapeutic index of leaves is 3.6. $\mathrm{LD}_{50}$ of the methanolic extract of leaves injected intraperitoneally was $2800 \mathrm{mg} / \mathrm{kg}$. LD 50 of stems administered orally was $4600 \mathrm{mg} / \mathrm{kg}$ so therapeutic index is 3.2 . LD $\mathrm{L}_{50}$ of stems methanolic extract injected intraperitoneally was 1500 $\mathrm{mg} / \mathrm{kg}$ (Table IV).

\section{Anti-diabetic and in vivo anti-oxidant activity}

Table $\mathrm{V}$ represents the effect of different extracts of 


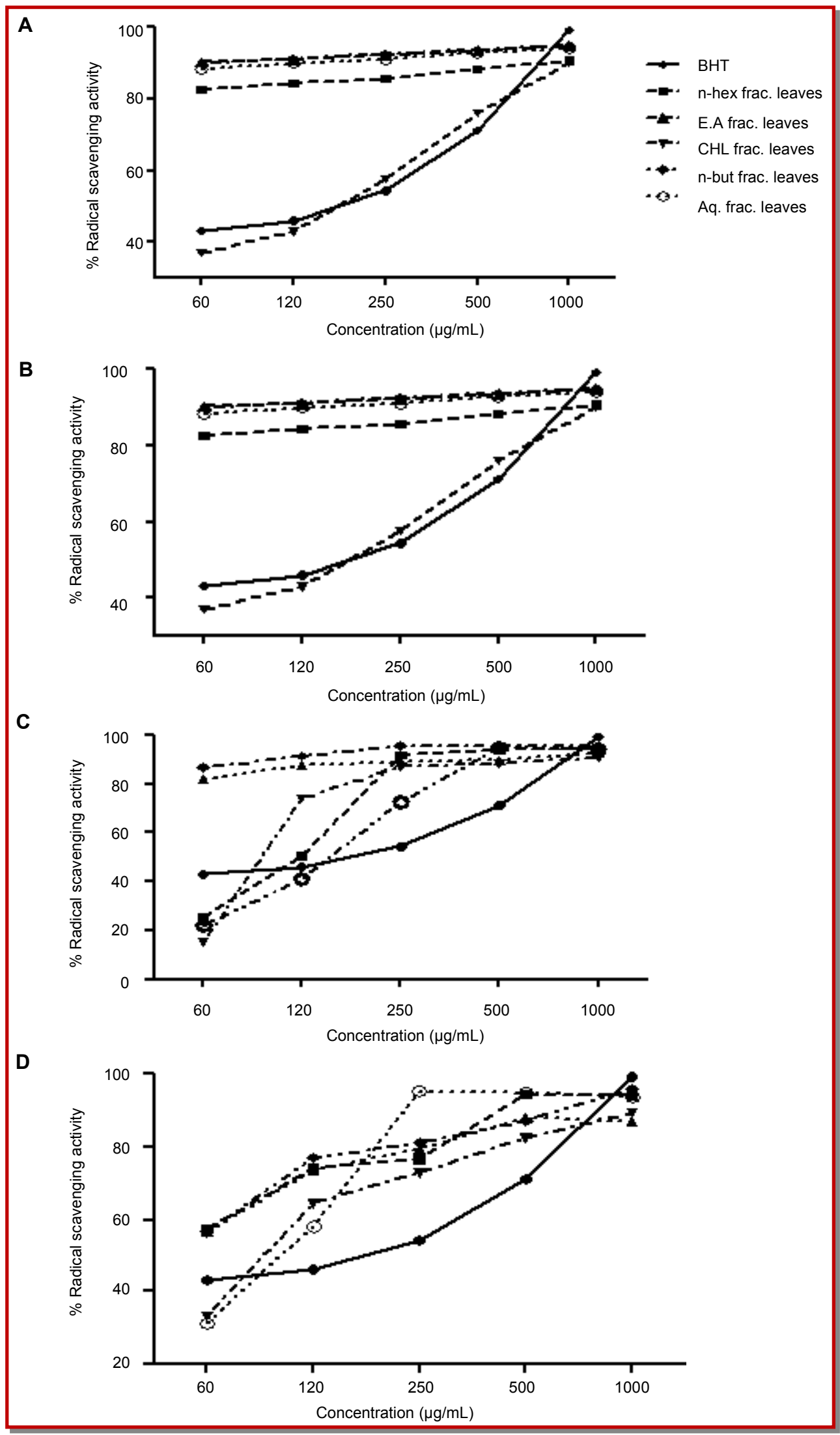

Figure 1: Comparison of DPPH radical scavenging activity. A \& B Comparison of percentage radical scavenging activity of various fractions of L. pulverulentus (D. sissoo) leaves and stems. C \& D Comparison DPPH radical scavenging action of several fractions of L. pulverulentus (P. nigra) 


\begin{tabular}{|c|c|c|c|c|c|}
\hline \multicolumn{6}{|c|}{ Table III } \\
\hline \multicolumn{6}{|c|}{$\begin{array}{l}\text { Total phenolic contents, flavonoids and anti-oxidant capacity of various fractions of L. pulverulentus } \\
\text { (D. sissoo) and L. pulverulentus (P. nigra) leaves and stems }\end{array}$} \\
\hline \multirow{11}{*}{$\begin{array}{l}\text { L. pulverulentus } \\
\text { (D. sissoo) }\end{array}$} & \multirow{6}{*}{ Leaves } & Sample & $\begin{array}{l}\text { Total phenols gallic } \\
\text { acid equivalent } \mathrm{mg} / \mathrm{g}\end{array}$ & $\begin{array}{l}\text { Total anti-oxidant activ- } \\
\text { ity equivalent to BHT } \\
\text { mg/g extract }\end{array}$ & $\begin{array}{l}\text { Total flavonoids } \mathrm{mg} / \mathrm{g} \\
\text { plant extract in querce- } \\
\text { tin equivalent }\end{array}$ \\
\hline & & HF & $196.4 \pm 2.2$ & $411.6 \pm 3$ & $493.4 \pm 1.7$ \\
\hline & & EAF & $214.5 \pm 3.6$ & $504.9 \pm 35.7$ & $336.1 \pm 6.5$ \\
\hline & & $\mathrm{CF}$ & $134.4 \pm 0.4$ & $137.9 \pm 6.5$ & $647.4 \pm 3.5$ \\
\hline & & $\mathrm{BF}$ & $208.1 \pm 3.0$ & $666.7 \pm 27.3$ & $475.5 \pm 0.7$ \\
\hline & & $\mathrm{AF}$ & $165.6 \pm 4.6$ & $214.7 \pm 1.8$ & $837.4 \pm 3.5$ \\
\hline & & $\mathrm{HF}$ & $90.7 \pm 1.2$ & $48.4 \pm 7.5$ & $501.4 \pm 2.4$ \\
\hline & & EAF & $171.9 \pm 3.1$ & $325.6 \pm 4.1$ & $571.4 \pm 2.9$ \\
\hline & Stems & $\mathrm{CF}$ & $70.6 \pm 0.3$ & $118.2 \pm 2$ & $282.1 \pm 3.7$ \\
\hline & & $\mathrm{BF}$ & $158.4 \pm 0.2$ & $463.3 \pm 6.3$ & $270.8 \pm 20$ \\
\hline & & $\mathrm{AF}$ & $117.3 \pm 2.2$ & $64.9 \pm 4.7$ & $158.1 \pm 1.7$ \\
\hline \multirow{10}{*}{$\begin{array}{l}\text { L. pulverulentus } \\
\text { (P. nigra) }\end{array}$} & \multirow{5}{*}{ Leaves } & $\mathrm{HF}$ & $31.8 \pm 0.3$ & $3.0 \pm 0.7$ & $117.4 \pm 2.4$ \\
\hline & & EAF & $6.8 \pm 0.1$ & $60.2 \pm 0.6$ & $100.8 \pm 3.0$ \\
\hline & & CF & $2.4 \pm 0.1$ & $68.2 \pm 0.3$ & $35.4 \pm 1.7$ \\
\hline & & $\mathrm{BF}$ & $82.4 \pm 0.2$ & $202.1 \pm 1.1$ & $122.8 \pm 1.1$ \\
\hline & & $\mathrm{AF}$ & $10.7 \pm 0.2$ & $219.9 \pm 0.7$ & $21.4 \pm 1.7$ \\
\hline & \multirow{5}{*}{ Stems } & $\mathrm{HF}$ & $4.12 \pm 0.3$ & $1.11 \pm 0.5$ & $56.8 \pm 3.1$ \\
\hline & & EAF & $9.51 \pm 0.1$ & $71.98 \pm 0.8$ & $160.1 \pm 2.9$ \\
\hline & & $\mathrm{CF}$ & $6.92 \pm 0.4$ & $0.57 \pm 0.4$ & $22.1 \pm 2.9$ \\
\hline & & $\mathrm{BF}$ & $14.51 \pm 0.5$ & $32.16 \pm 0.4$ & $78.8 \pm 1.2$ \\
\hline & & $\mathrm{AF}$ & $3.80 \pm 0.1$ & $22.68 \pm 1.2$ & $42.1 \pm 3.7$ \\
\hline
\end{tabular}

Data is presented as Mean \pm SEM; HF: n-hexane fraction; EAF: ethyl acetate fraction; CF: chloroform fraction; BF: n-butanol fraction; AF: aqueous fraction

leaves and stems on glucose and oxidative levels in alloxan-treated diabetic mice. The methanolic extracts of leaves and stems were analyzed at 250 and $500 \mathrm{mg} /$ $\mathrm{kg}$ doses and significant results were obtained when compared with control diabetic group. The anti-diabetic effect evaluated showed that ethyl acetate $(\% \downarrow 35.7)$, nbutanol $(\% \downarrow 46.7)$ and aqueous $(\% \downarrow 49.4)$ fractions of the leaves were most active in reducing glucose levels after seven days treatment. The $n$-butanol fraction significantly reduced oxidative stress. The methanolic extract of stems significantly decreased glucose levels. All the fractions of the stems didn't highly significantly reduce the glucose levels. Ethyl acetate $(\% \downarrow 22.0)$ fraction of the stems was most active in reducing the glucose levels on eighth day after treatment.

\section{Discussion}

Phytochemical analysis of the methanolic extract of $L$. pulverulentus (D. sissoo) leaves and stems indicated absence of saponins whereas flavonoids, phenols, triterpenoids, carbohydrates and glycosides gave intense reactions. During single dose study significant blood glucose reduction was observed at $6^{\text {th }}$ hours with L. pulverulentus (D. sissoo) extract and the effect extended up to 24 hours whereas the methanolic extract of stems couldn't maintain significant glucose reduction up to 24 hours. There was no significant decrease in 
Table IV

Effect of methanolic extracts of L. pulverulentus (D. sissoo and P. nigra) in diabetic mice

\begin{tabular}{|c|c|c|c|c|c|c|c|}
\hline Groups & 0 hour & 2 hours & 4 hours & 6 hours & 8 hours & 12 hours & 24 hours \\
\hline Control & $294 \pm 9.6$ & $297 \pm 8.9$ & $311 \pm 18.3$ & $314 \pm 6.7$ & $307 \pm 7.3$ & $303 \pm 5.4$ & $297 \pm 9.9$ \\
\hline $\begin{array}{l}\text { L. pulverulentus } \\
\text { (D. sissoo) leaf }\end{array}$ & $268 \pm 9.6$ & $268 \pm 4.5$ & $238 \pm 12.8$ & $161 \pm 5.5^{a}$ & $150 \pm 3.8^{a}$ & $152 \pm 5.8^{a}$ & $219 \pm 8.2^{a}$ \\
\hline $\begin{array}{l}\text { L. pulverulentus } \\
\text { (D. sissoo) stem }\end{array}$ & $296 \pm 12.3$ & $292 \pm 11.7$ & $274 \pm 12.7$ & $212 \pm 10.8^{a}$ & $229 \pm 11.4^{b}$ & $247 \pm 7.5^{c}$ & $294 \pm 9.4$ \\
\hline $\begin{array}{l}\text { L. pulverulentus } \\
\text { (P. nigra) leaf }\end{array}$ & $301 \pm 14.1$ & $308 \pm 10.6$ & $273 \pm 11.4$ & $261 \pm 11.7$ & $250 \pm 7.91^{b}$ & $279 \pm 6.4$ & $302 \pm 8.1$ \\
\hline $\begin{array}{l}\text { L. pulverulentus } \\
\text { (P. nigra) stem }\end{array}$ & $294 \pm 13.3$ & $307 \pm 12.5$ & $310 \pm 7.7$ & $289 \pm 7.29$ & $299 \pm 6.9$ & $289 \pm 7.6$ & $298 \pm 9.6$ \\
\hline
\end{tabular}

Data is presented as mean $\pm \mathrm{SEM} ; \mathrm{n}=5$; Control diabetic group is compared with all groups, ${ }^{\mathrm{p}} \mathrm{p}<0.001,{ }^{\mathrm{b}} \mathrm{p}<0.01,{ }^{\mathrm{c}} \mathrm{p}<0.05$ (Dunnett test with $95 \%$ confidence interval)

\section{Table V}

Effect of various fractions of L. pulverulentus (D. sissoo) leaves and stems on glucose and total anti-oxidant activity in alloxan-treated diabetic mice

\begin{tabular}{|lcccc|}
\hline Sample & $\begin{array}{c}\text { Glucose }(\mathrm{mg} / \mathrm{dL}) \\
\text { level on day } 7 \\
\text { (leaves) }\end{array}$ & $\begin{array}{c}\text { Total AOA (mmol/L) } \\
\text { on day 7 } \\
\text { (leaves) }\end{array}$ & $\begin{array}{c}\text { Glucose (mg/dL) } \\
\text { level on day 7 } \\
\text { (stems) }\end{array}$ & $\begin{array}{c}\text { Total AOA } \\
\text { (mmol/L) on day 7 } \\
\text { (stems) }\end{array}$ \\
\hline Control group & $94 \pm 2.8$ & $2.08 \pm 0.1$ & $94 \pm 2.8$ & $2.08 \pm 0.1$ \\
Control diabetic group & $280.2 \pm 7.9^{\mathrm{a}}$ & $0.88 \pm 0.0^{\mathrm{a}}$ & $280.2 \pm 7.9^{\mathrm{a}}$ & $0.88 \pm 0.0^{\mathrm{a}}$ \\
Metformin treated group & $207.6 \pm 5.1^{\mathrm{a}}$ & $1.77 \pm 0.1^{\mathrm{a}}$ & $207.6 \pm 5.1^{\mathrm{a}}$ & $1.77 \pm 0.1^{\mathrm{a}}$ \\
Methanolic extract $(250 \mathrm{mg} / \mathrm{kg})$ & $183 \pm 5.0^{\mathrm{a}}$ & $1.84 \pm 0.2^{\mathrm{a}}$ & $213 \pm 7.6^{\mathrm{a}}$ & $1.59 \pm 0.2^{\mathrm{b}}$ \\
Methanolic extract $(500 \mathrm{mg} / \mathrm{kg})$ & $187 \pm 8.1^{\mathrm{a}}$ & $1.84 \pm 0.5^{\mathrm{a}}$ & $190 \pm 3.0^{\mathrm{a}}$ & $1.85 \pm 0.1^{\mathrm{a}}$ \\
$n$-Hexane fraction & $232.6 \pm 11.5^{\mathrm{b}}$ & $1.38 \pm 0.2$ & $255.6 \pm 11.1$ & $1.38 \pm 0.2^{\mathrm{c}}$ \\
Ethyl acetate fraction & $179 \pm 12.2^{\mathrm{a}}$ & $1.54 \pm 0.2^{\mathrm{b}}$ & $220.6 \pm 11.8^{\mathrm{a}}$ & $1.29 \pm 0.1$ \\
Chloroform fraction & $265 \pm 12.4$ & $0.98 \pm 0.1$ & $262 \pm 9.0$ & $0.98 \pm 0.1$ \\
$n$-Butanol fraction & $156.2 \pm 15.2^{\mathrm{a}}$ & $1.7 \pm 0.2^{\mathrm{a}}$ & $254 \pm 16.3$ & $1.29 \pm 0.1$ \\
Aqueous fraction & $146.6 \pm 4.3^{\mathrm{a}}$ & $1.48 \pm 0.2^{\mathrm{c}}$ & $258.2 \pm 8.8$ & $1.31 \pm 0.1$ \\
\hline
\end{tabular}

Data is presented as mean \pm SEM; Control diabetic group is compared with all groups, ap $<0.001,{ }^{b} p<0.01$, ${ }^{c} p<0.05$ (Dunnett test with $95 \%$ confidence interval

blood glucose with L. pulverulentus (P. nigra) leaves and stems extract. The present study indicated that nbutanol fraction of leaves of L. pulverulentus (D. sissoo) had highest radical scavenging activity in relevance to BHT (\% inhibition 92.4\%). The phenolic content in $n$ butanol fraction of leaves of L. pulverulentus (D. sissoo) was $208.1 \pm 3.1 \mathrm{GAE} \mathrm{mg/g}$ whereas total flavonoid content was $475.5 \pm 0.7$ Quer/g of extract. Highest total in vitro anti-oxidant in $n$-butanol fraction was $666.7 \pm$ $27.3 \mathrm{mg} / \mathrm{g}$ equivalent to BHT whereas in vivo $n$-butanol $(1.7 \pm 0.1 \mathrm{mmol} / \mathrm{L})$ and aqueous $(1.5 \pm 0.2 \mathrm{mmol} / \mathrm{L})$ fractions were equally effective. The $n$-butanol fraction was equally effective as metformin $(1.8 \pm 0.1 \mathrm{mmol} / \mathrm{L})$ in increasing in vivo anti-oxidant status. The $n$-butanol fraction of L. pulverulentus (D. sissoo) significantly increased the anti-oxidant status $(1.7 \pm 0.2)$ when compared with the control diabetic group $(0.8 \pm 0.0)$.
The $n$-butanol fraction significantly reduced the glucose levels up to $46.7 \%$ after seven days treatment whereas metformin decreased blood glucose levels to $25.9 \%$ when compared with diabetic control group.

Animal models can be easily used to calculate therapeutic index of a particular drug. The therapeutic index of leaves is 3.5. This indicates that the leaves have good margin of safety, so extract of leaves can be safely used therapeutically in diabetic patients. $\mathrm{LD}_{50}$ of the leaves when given through oral route was $6,500 \mathrm{mg} / \mathrm{kg}$, suggesting that below this dose the extract could be safely used orally. $\mathrm{LD}_{50}$ of the leaves injected intraperitoneally was $2,800 \mathrm{mg} / \mathrm{kg}$. For the determination of $\mathrm{ED}_{50}$ of leaves minimum dose $(100 \mathrm{mg} / \mathrm{kg})$ was selected and fractional increase in dose increased the hypoglycaemic response. The therapeutic index of stems is 3.2 and $E D_{50}$ 
of stems calculated was $1,450 \mathrm{mg} / \mathrm{kg}$. $\mathrm{LD}_{50}$ of methanolic extract of stems given orally was $4,600 \mathrm{mg} / \mathrm{kg}$ whereas when injected intraperitoneally was $1,500 \mathrm{mg} /$ $\mathrm{kg}$. The methanolic extract of stems has low margin of safety and doesn't possess very significant activity in controlling blood glucose levels.

The in vitro anti-oxidant results comply with previous published results with slight variation that could be attributed to the time of the collection of plant. In our results the maximum DPPH scavenging ability in leaves was found in $n$-butanol fraction that varies with the previous published results where ethyl acetate fraction showed maximum inhibition. In stems, however, the maximum DPPH percentage inhibition was found in ethyl acetate fraction and our results comply with previous published results (Raza et al., 2013).

The beneficial effects of plants have been attributed to the presence of phenolic compounds, which have the ability to trap the oxidants generated during diabetic stress. Phytochemical analysis indicated presence of flavonoids and phenols in plant extract. These compounds found in the $n$-butanol fraction have higher radical scavenging ability which can greatly reduce oxidative stress in diabetic condition. Saponins completely absent in L. pulverulentus (D. sissoo), are responsible for hemolytic effect, so will not cause haemolysis of RBC's whereas L. pulverulentus (P. nigra) contains saponins (Gee and Johnson, 1988). Alloxan causes oxidative damage to pancreatic beta islets by producing superoxide and hydroxyl ions. Alloxan induced chemical diabetic model is most suitable for assessing the in vivo anti-oxidant potential of a drug (Lenzen, 2008). The in vivo anti-oxidant activity was evaluated spectrophometrically by assessing the suppression of thiobarbituric acid reactive substances. The thiobarbituric acid reactive substances were suppressed by the anti-oxidants present in serum. The fractions that significantly reduced the glucose levels are polar in nature as $n$-butanol and aqueous fractions solubilize more polar compounds. It could be suggested that polar compounds are more active in reducing the glucose levels and have potential in vivo anti-oxidant activity. Metformin has no defined cellular mechanism. It increases hepatic glucose utilization and decreases hepatic glucose production (Zhou et al., 2001). It could be suggested that $n$-butanol fraction of leaves might have some cellular mechanisms through which glucose uptake may be increased in liver and muscle. The in vivo anti-oxidant assay showed that $\mathrm{n}$-hexane fraction of stems also possesses significant anti-oxidant action $(1.4 \pm 0.2)$ whereas it didn't significantly reduce the glucose levels $(255.6 \pm 11.1)$ in alloxan-treated diabetic mice. This suggests that presence of anti-oxidant activity alone is not capable of treating diabetic disease. In stems, significant blood glucose levels were reduced in mice treated with ethyl acetate fraction (\% $\downarrow$ 22.0). This shows that that this fraction contains some compounds other than anti-oxidants capable of reducing blood glucose levels.

\section{Conclusion}

Polar fractions of leaves of L. pulverulentus (D. sissoo) have significant anti-oxidant and anti-diabetic activity whereas in stems very significant anti-diabetic potential was not observed. L. pulverulentus (P. nigra) doesn't possess anti-diabetic activity whereas potential antioxidant activity was observed. The leaves of $L$. pulverulentus (D. sissoo) have large therapeutic index and can be recommended for further scientific evaluation of mechanism of anti-diabetic action.

\section{Ethical Issue}

The Animal Ethical Committee approved the protocol of this study and issued Ethical Approval certificate, AEC/UCP/1028/4313.

\section{Conflict of Interest}

There is no conflict of interest to declare.

\section{Acknowledgement}

This study was supported and funded by University College of Pharmacy, University of the Punjab.

\section{References}

Adesina SK, llloh HC, Johnny ll, Jacobs IE. African mistletoes (Loranthaceae), ethnopharmacology, chemistry, medicinal values: An update. Afr J Tradit Complement Altern Med, 2013; 10: 161-70.

Ajaib M, Khan Z, Khan M, Wahab M. Ethnobotanical studies on useful shrubs of district Kotli, Azad Jammu \& Kashmir, Pakistan. Pakistan J Bot. 2010; 42: 1407-15.

Evans WC. Trease and Evans pharmacognosy. Elsevier Health Sciences, 2009.

Gee J, Johnson I. Interactions between hemolytic saponins, bile salts and small intestinal mucosa in the rat. J Nutr. 1988; 118: 1391-97.

GöktürkBaydar N, Özkan G, Yaşar S. Evaluation of antiradical and anti-oxidant potential of grape extracts. Food Control. 2007; 18: 1131-36.

Ishtiaq S, Ahmad M, Hanif U, Akbar S, Kamran SH. Phytochemical and in vitro anti-oxidant evaluation of different fractions of Amaranthus graezians subsp. Silvestris (Vill.) Brenan. Asian Pac J Trop Med. 2014; 7: S342-47 
Koracevic D, Koracevic G, Djordjevic V, Andrejevic S, Cosic V. Method for measurement of anti-oxidant activity in human fluids. J Clin Pathol. 2001; 54: 356-61.

Lenzen S. The mechanism of alloxan- and streptozocininduced diabetes. Diabetologica 2008; 51: 216-26.

Lorke D. A new approach to practical acute toxicity testing. Arch Toxicol. 1983; 54: 275-87.

OECD. 420: Acute oral toxicity-fixed dose procedure. OECD guidelines for testing of chemicals, 2001, pp 1-14.

ÖnayUçar E, Karagöz A, Arda N. Anti-oxidant activity of Viscum album ssp. Album. Fitoterapia 2006; 77: 556-60.

Raza MA, Kausar R, Rana FA, Danish M, Shahwar D, Anwar F. Lorathus pulveulentus: A potent source of natural anti- oxidants and alternative medicine. J Chem. 2013; 2013.

Sabu M, Kuttan R. Anti-diabetic activity of medicinal plants and its relationship with their anti-oxidant property. J Ethnopharmacol. 2002; 81: 95-102.

Singleton VL, Orthofer R, Lameula-Raventos RM. Analysis of total phenols and other oxidation substrates and antioxidants by means of Folin-Ciocalteu reagent. Methods Enzymol. 1999; 299: 152-78.

Stahl E. Thin-layer chromatography. A laboratory handbook. $2^{\text {nd }}$ ed. Heidelberg, Springer-Verlag Berlin, 1967, pp 855-904.

Subhan F, Abbas M, Rauf K, Baseer A. Anti-GIT motility, toxicological and phytochemical studies on Bacopa monnieri. Pharmacology Online. 2010; 3: 937-95. 


\section{Your feedback about this paper}

1. Number of times you have read this paper 0

2. Quality of paper Click

3. Your comments

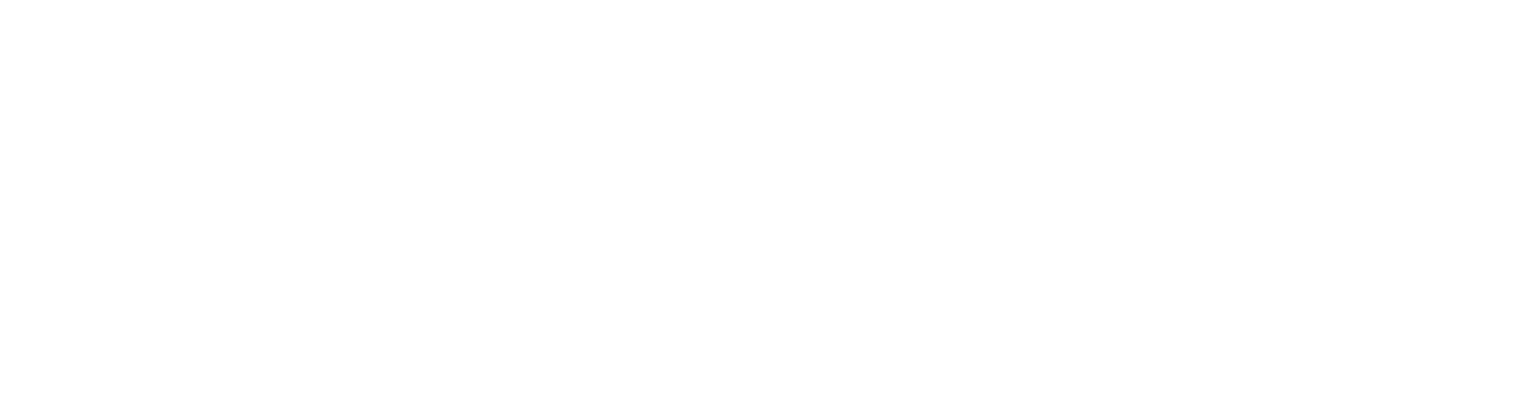

